\title{
Ahli Waris Pengganti Di Indonesia Dengan Historisitasnya
}

\author{
Muhamad Sauki Alhabsyi \\ Universitas Islam Negeri (UIN) Datokarama Palu \\ Syahrul Mubarak Subeitan \\ Institut Agama Islam Negeri (IAIN) Manado
}

\begin{abstract}
Abstrak
Perkara kewarisan merupakan salah satu bidang yang diatur secara spesifik dalam hukum Islam, baik penentuan siapa-siapa yang berhak (dzawil furudh, ashabah, dan dzawil arham) serta detil jumlah pembagiannya di dalam Al-Qur'an. Meskipun begitu, seiring perkembangan zaman muncul permasalahan-permasalahn dan isu-isu waris yang "kontemporer"termasuk masalah ahli waris pengganti. Dalam kitab-kitab figh atau bukubuku yang ditulis para yuris Islam tidak mengenal sebutan ahli waris pengganti ataupun pergantian kedudukan ahli waris pengganti (plaatvervulling) seperti yang tersebut dalam Pasal 185 Kompilasi Hukum Islam. Ini merupakan dekonstruksi atas pendapat umum dalam hukum kewarisan Islam. Penelitian ini kemudian menyoroti aspek historis tentang kehadiran Ahli Waris Pengganti dalam hukum kewarisan di Indonesia, dengan menggunakan model penelitian library research dengan pendalaman kesejarahan terhadap penerapan suatu hukum.
\end{abstract}

Kata Kunci: Ahli Waris Pengganti, Kewarisan, Histori

\begin{abstract}
The case of inherition is one of the areas specifically regulated in Islamic law, both the determination of who is entitled (dzawil furudh, ashabah, and dzawil arham) and the details of the number of divisions in the Qur'an. However, with the times came problems and issues of "contemporary" heirs including the issue of replacement heirs. In the books of figh or books written by Islamic jurists do not recognize the designation of a replacement heir or the change of position of a replacement heir (plaatvervulling) as mentioned in Article 185 compilation of Islamic law. This is a deconstruction of public opinion in Islamic inherited law. This research then highlights the historical aspect of the presence of Surrogate Heirs in inheritance law in Indonesia, using a library research model with historical deepening of the application of a law.
\end{abstract}

Keywords: Replacement Heirs, Inherities, History 


\section{A. Pendahuluan}

Islam mengatur ketentuan pembagian warisan secara rinci agar tidak terjadi antara sesame ahli waris sepeninggal orang yang hartanya diwarisi. Agama islam menghendaki prinsip adil dan keadilan sebagai salah satu sendi pembinaan masyarakat dapat ditegakan. Ketentuan tersebut tidak dapat berjalan baik dan efektif tanpa ditunjang oleh tenaga-tenaga ahli yang memahami dan melaksanakan ketentuan-ketentuan tersebut dengan baik. ${ }^{1}$

Kewarisan mengalami perkembangan yang sangat berarti bagi umat islam di Indonesia, dan itu disebabkan oleh kebutuhan masyarakat yang semakin kompleks dan pola pemikirannya biasa berubah sesuai dengan perubahan zaman. Diantara hukum kewarisan islam yang mengalami perkembangan adalah adanya ahli waris penganti, yang penerapannya di Indonesia telah diatur KHI. Istilah ahli waris pengganti memang tidak dikenal didalam Al- Qur'an namun kedudukannya sebagai ahli waris dapat diketahui melalui perluasan pengertian ahli waris langsung yang dijelaskan dalam Al-Qur'an.

Ahli waris pengganti dalam hukum kewarisan islam untuk melengkapi hukumhukum yang telah ada dan juga bertujuan untuk mencari rasa keadilan bagi ahli waris. Waris pengganti pada dasarnya adalah ahli waris karena penggantian yaitu orang-orang yang menjadi ahli waris karena orang tuanya yang berhak mendapatkan warisan telah meningal lebih dahulu dari pewaris, sehingga dia tampil menggantikan. ${ }^{2}$

Seiring dengan perkembangan Islam di dunia hingga saat ini, upaya pemberlakuan hukum Islam masih terus dilakukan. Persoalan yang mendasar mengenai ahli waris pengganti yang bertujuan untuk memenuhi rasa keadilan bagi ahli waris. Pada dasarnya ahli waris pengganti menjadi ahli waris karena orang tuanya telah meninggal lebih dahulu dari pewaris. Di Indonesia hingga sekarang, konflik tentang hukum waris Islam terutama antara kelompok tradisionalis dengan kalangan yang menamakan dirinya kelompok modernis masih merupakan fenomena yang mengisi teks-teks hukum waris Islam, walaupun dapat dipastikan

\footnotetext{
${ }^{1}$ Ahmad Rofiq, Fiqih Mawaris, II. (Jakarta: PT. Raja Grafindo Persada, 1995).

${ }^{2}$ Ahmad Azhari, Hukum Kewarisan Islam (Pontianak: FHLM Untan Press, 2008).
} 
doktrin fiqh waris sunni pro-Syafi'I yang banyak dianut dalam masyarakt muslim Indonesia. Hal ini terkait dengan kesejahteraannya yang panjang sejak masuknya Islam di Indonesia. ${ }^{3}$

Meskipun pada bagian-bagian tertentu di dalamnya ditemukan refleksi-refleksi pemikiran baru untuk mengisi ruang kosong dalam rangka penyesuaian dengan kondisi-kondisi di Indonesia antara lain tentang ahli waris pengganti.

Berdasarkan latar belakang diatas maka penulis merasa perlunya pembahasan ahli waris penganti di Indonesia yang meliputi pokok permasalahan diantaranya: Kewarisan di Indonesia, Ahli Waris Pengganti, Historisitas dan Dasar Hukum Ahli Waris Pengganti, Ahli Waris Penganti Menurut Hukum Islam, dan Ahli WAris Pengganti Menurut KHI.

\section{B. Kewarisan di Indonesia}

Menurut ajaran kewarisan patrilinial Syafi'ih di Indonesia, ahli waris dapat digolongkan menjadi tiga golongan, yaitu : Ahli Waris Dzul fara'idh, Ahli Waris Ashabah dan Ahli Waris Dzul Arham. ${ }^{4}$

\section{Ahli Waris Dzul Fara'idh}

Kelompok ini yaitu ahli waris ${ }^{5}$ yang mendapatkan bagian tertentu menurut ketentuan Al-Qur'an, Adapun jumlah yang diterima masing-masing ahli waris

\footnotetext{
${ }^{3}$ Rahmat Djatnika, Sosialisasi Hukum Islam Dalam Kontroversi Pemikiran Islam Di Indonesia, 2nd ed. (Bandung: Remaja Rodakarya, 1993).

${ }^{4}$ Sajuti Thalib, Hukum Kewarisan Islam Di Indonesia, Revii Cet. (Jakarta: Sinar Grafika, 2016).

${ }^{5}$ Ahli Waris dari golongan laki-laki ada 15 : anak laki-laki, cucu laki-laki dari anak laki-laki sampai kebawah, Ayah dan ayahnya ayah sampai ke atas, Saudara laki-laki sekandung, Saudara seayah, Saudara seibu, Anak Laki-laki saudara sekandung, Anak Laki- laki saudara laki-laki seayah sampai kebawah, Paman kandung, Paman seayah, Anak laki-laki paman sekandung, Anak laki-laki paman seayah sampai kebawah, Suami/duda, Laki-laki yang memerdekakan budak, Sedangkan ahli waris dari golongan perempuan ada 10: Anak perempuan, Cucu perempuan dari anak laki-laki sampai kebawah, Ibu, Nenek dari Ibuh, Nenek dari ayah sampai keatas, Saudara perempuan sekandung, Saudara perempuan seayah, Saudara perempuan seibu, Istrri/janda, Perempuan yang memerdekakan budak. Dari penjelasan di atas yang mendapatkan bagian tertentu adalah semua golongan perempuan kecuali perempuan yang memerdekakan budak dan tidak mendapatkan bagian tertentu dari golongan laki-laki kecuali suami/duda dan saudara laki-laki seibu, dan juga ayah dan kakek dari ayah Muhammad Bin Salim, Fiqih Mawaris, 1st ed. (Tarim (Hadramaut): Dar al-Fikr, 2005). Dari penjelasan diatas penulis dapat memahami bahwa yang mendapatkan bagian tertentu ada 13 yaitu : istri, anak perempuan, cucu perempuan dari anak laki-laki sampai kebawah, ibu, nenek
} 
yakni, seperdua $(1 / 2)$, seperempat $(1 / 4)$, seperdelapan $(1 / 8)$, dua pertiga $(2 / 3)$, sepertiga $(1 / 3)$, seperenam $(1 / 6){ }^{6}$

\section{Ahli Waris Ashabah}

Kelompok ini yaitu ahli waris yang tidak ditentukan berapa besar bagiannya, namun ia berhak menghabisi semua harta jika mewaris seorang diri, atau menghabisi semua sisa harta jika mewaris bersama sama dengan ahli waris dzawil furuid. Yang berhak menerimah ashabah adalah semua dari golongan laki-laki kecuali suami/duda dan saudara seibu. ${ }^{7}$ Konsep ashabah tidak ditemukan dalam al-Qur'an dan merupakan hasil interpretasi mujtahid terhadap hadits Ibn 'Abbas:

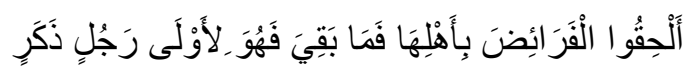

Artinya:

“Berikanlah bagian-bagian ahl al-fara'id, dan apa yang tersisa darinya untuk kerabat laki-laki paling dekat" ${ }^{8}$

Ahli waris ashabah dibagi menjadi tiga, yaitu: ashabah binafsih yaitu ahli waris ashabah karena dirinya sendiri, bukan karena bersama dengan ahli waris lainnya. Yaitu semua dari golongan laki-laki kecuali suami/duda dan saudara laki-laki seibu. Ashabah bil ghairi yaitu ahli waris ashabah karena mewaris bersama ahli waris lainnya, maksudnya perempuan yang ditarik oleh saudaranya yang lakilaki, sehingga bersama sama menjadi ashabah, misalnya anak perempuan bersama anak laki-laki atau saudarah perempuan sekandung bersama saudarah laki-laki sekandung. Ashabah ma'al ghairi yaitu ahli waris yang terdiri dari saudarah perempuan kandung atau saudara perempuan seayah dengan anak perempuan atau cucu perempuan dari anak laki-laki kebawah. ${ }^{9}$

dari ibu, nenek dari ayah sampai keatas, saudara perempuan sekandung, saudarah perempuan seayah, saudarah perempuan seibu, suami,/duda saudara laki-laki seibu, ayah dan kakek.

${ }^{6}$ Ibid.

${ }^{7}$ Ibid.

${ }^{8}$ Ahmad bin Ali bin Hajar al-Asqalani, Fath Al-Bari Syarh Sahih Al-Bukhari (Beirut: Dar ar-Riyan li at- Turas, 1986).

${ }^{9}$ Bin Salim, Fiqih Mawaris. 
Dari ketiga jenis ashabah tersebut, dapat kita lihat bahwa hanya orang lakilaki atau orang perempuan dari garis laki-laki saja yang dapat menjadi asabah. Cucu perempuan dari anak perempuan dan saudara perempuan seibu misalnya, jelas tidak menjadi ahli waris asabah.

Apabilah ashabah misalnya anak laki-laki, ayah, kakek, saudara laki-laki (kandung / seayah), anak saudara laki-laki (kandung / seayah) dan paman. maka dari segi terdepan akan menghijab setelahnya, dan apabilah sama maka yang harus di dahulukan yang paling dekat missal anak laki-laki bersama kakek maka yang didahulukan anak laki-laki dan kakek terhijab olehnya. Kemudian apabila derajatnya sama misalnya saudara kandung bersama saudara seayah dalam kasus ini nasab keduanya sama yaitu ke ayah mereka akan tetapi saudara kandung lebih dekat dikarenakan ada hubungannya dengan si mayit sedangkan saudara seayah tidak ada hubungan dengan mayit maka didahulukan saudara kandung.

\section{Ahli Waris Dzul Arham}

Merupakan ahli waris yang mempunyai hubungan darah dengan pewaris melalui anggota keluarga dari pihak perempuan, yang termasuk dalam kategori ini misalnya cucu dari anak perempuan, anak saudara perempuan, anak perempuan saudara laki- laki, anak perempuan paman, paman seibu, saudara laki-laki ibu dan saudara perempuan ibu/bibi.

Para ulama berbeda pendapat dalam menentukan apakah ahli waris $d z u l$ arham dapat mewaris atau tidak. Ada dua pendapat tentang hal ini, yaitu : yang pertama menurut mazhab Maliki, dzul arham tidak berhak sama sekali mendapat warisan, karena jika tidak ada kerabat laki-laki yang bertindak sebagai ashabah, maka sisa harta warisan akan dialihkan kepada Bait al Mal. Sementara menurut mazhab Hanafi, Syafi'i, dan Hanbali dzul arham berhak mendapatkan warisan, dengan syarat tidak ada $d z u l$ fara'idh dan ashabah. Hanya saja, karena 
dua pihak tersebut hampir selalu ada dalam perkara kewarisan, maka kesempatan $d z u l$ arham untuk mendapatkan bagian warisan sangat tipis. ${ }^{10}$

Dari kedua pendapat tersebut dapat satu hal yang jelas bagi kita yaitu sepanjang masih ada ahli waris dzul fara'idh atau ahli waris ashabah, ahli waris dzawil arham tak mungkin mewarisi.

\section{Kewarian di Indonesia}

Ahli waris pengganti pada umumnya diberi makna, orang yang tampil sebagai ahli waris karena menggantikan kedudukan orang tuanya yang meninggal dunia lebih dahulu dari pewaris.

Adapun yang dimaksud dengan ahli waris pengganti menurut Sajuti Thalib adalah ahli waris yang menggantikan seseorang untuk memperoleh bagian warisan yang pada mulanya akan diperoleh dari orang yang digantikannya itu adalah orang yang seharusnya menerima warisan kalau dia masi hidup. Orang yang digantikannya ini hendaklah merupakan penghubung antara dia yang menggantikan ini dengan pewaris yang meninggalkan harta peninggalan. ${ }^{11}$

Dalam buku Al-Yasa Abu Bakar yang berjudul Ahli Waris Sepertalian Darah, ahli waris pengganti dalam hukum adat dalah orang-orang yang hubungannya dengan pewaris diselingi oleh ahli waris, tapi telah meningal terlebih dahulu dari pewaris. Sebab, sekirahnya ahli waris itu masi hidup tentu kehadiran ahli waris pengganti tidak perlu diperhitungkan. ${ }^{12}$

\section{Dasar Hukum Ahli Waris Pengganti}

Pada ranah normatif, peranan penting kewarisan dalam Islam dapat juga dilihat dari begitu terperincinya aturan-aturan yang telah ditentukan dalam al-Qur'an yang berkaitan dengan pembagian waris. Ayat-ayat tentang waris (Q.S. An-Nisa': 11-12 dan 176) telah menjelaskan secara terperinci mengenai cara pembagian harta waris,

${ }^{10}$ N.J Coulson, Succession in the Muslim Family (Cambridge: The University Press, 1971).

${ }^{11}$ Sajuti Thalib, Hukum Kewarisan Islam Di Indonesia, 8th ed. (Jakarta: Sinar Grafika, 2004).

12 Al Yasa Abubakar, Ahli Waris Sepertalian Darah: Kajian Perbandingan Terhadap Penalaran Hazairin Dan Penalaran Fiqih Madzhab (Jakarta: INIS, 1998). 
kelompok ahli waris, dan jumlah besarnya bagian masing-masing ahli waris. Hal-hal ini telah diatur dalam ketentuan yang pasti dalam sumber utama hukum Islam.

Para fuqaha' terutama dari kalangan Malikiyah, Syafi'iyah dan Hanabilah memahami hukum kewarisan islam sebagai hukum yang sudah, rigit dan pasti, sehingga tidak mungkin diberikan tafsiran atau makna lain, selain yang tersebut secara eksplisit dalam teks Al-Qur'an dan Al-Hadits. ${ }^{13}$ Pandangan para fuqaha' ini telah melahirkan postulat bahwa hukum kewarisan Islam bersifat qathi'iy. Pandangan ini telah mewarnai sebagian besar pemikiran masyarakat Muslim. Bukubuku fiqih klasik, tidak memberikan ruang untuk konsep ini, sehingga tidak pernah ditemukan adanya pengakuan terhadap lembaga pergantian tempat ahli waris, dengan alasan tidak ada teks Al-Qur'an dan Al-Hadits mengenai hal ini. Ketentuan mengenai siapa ahli waris dan bagian dari masing-masing dari harta warisan telah ditetapkan secara pasti oleh Al-Qur'an dan Al-Hadits. Ketentuan siapa-siapa ahli waris dan furudh al-muqaddarah ini, tidak mungkin dilakukan perubahan dan interpretasi lain, karena ketentuan ini bersifat qathi'iy.

Konstruksi fiqh waris yang tekstual ini ternyata berbanding terbalik dengan realitas hukum sehari-hari yang dipraktikan oleh masyarakat muslim, terutama masyarakat yang sangat kental dengan hukum adat. Bila diteliti lebih jauh, banyak masalah kewarisan yang tumbuh dan berkembang dalam masyarakat yang memerlukan tafsiran baru dan ijtihad, sehingga hukum kewarisan Islam mampu memenuhi kebutuhan hukum masyarakat. Kehadiran para pemikir muslim seperti Ibn Katsir, Imam Thabary, Imam Qurtuby, Abduh, Imam Maraghi, Ali AsShabuni, Sayyid Sabiq, Yusuf Musa, Fazlurrahman, Yusuf Qaradhawy dan berbagai pemikir lain telah memberikan nuansa baru terhadap pemikiran hukum kewarisan Islam. ${ }^{14}$

Para pemikir ini memberikan tafsiran baru terhadap beberapa ketentuan dalam hukum kewarisan termasuk di antaranya mengenai 'pergantian tempat ahli waris'. Para pemikiran kontemporer cenderung memberikan hak waris kepada cucu

${ }_{13}$ Muhammad Ali As Shabuni, Terjemahan: Hukum Waris Dalam Syari'at Islam (Bandung: Diponegoro, 1988).

${ }^{14}$ Hisyam Hoballah, Understanding Islamic Law: From Classical and Contemporary (Oxford: Altamira Press, 2006). 
walaupun ayahnya telah terlebih dahulu meninggal dunia. Persoalan pergantian tempat ahli waris adalah persoalan ijtihadiyah, dan ternyata dalam fiqh kewarisan yang dibangun oleh ulama klasik menyimpan problema yang harus diselesaikan dalam konteks kekinian. Landasan utama hukum kewarisan adalah ayat al-Qur'an terutama dalam Q.S An-Nisaa' [4]: 11

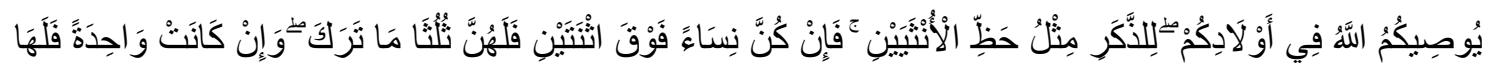

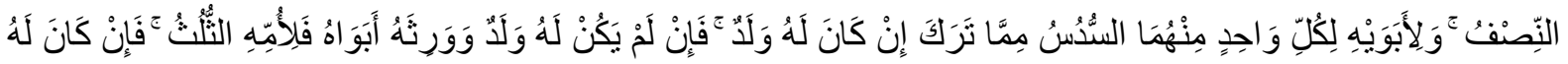

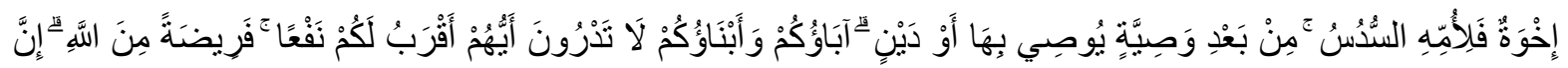
السَّ كَانَ عَلِيمًا حَكِيمًا

Yang artinya:

“Allah mensyari'atkan bagimu tentang (pembagian pusaka untuk) anak-anakmu. Yaitu: bahagian seorang anak lelaki sama dengan bagahian dua orang anak perempuan; dan jika anak itu semuanya perempuan lebih dari dua, maka bagi mereka dua pertiga dari harta yang ditinggalkan; jika anak perempuan itu seorang saja, maka ia memperoleh separo harta. Dan untuk dua orang ibu-bapa, bagi masing-masingnya seperenam dari harta yang ditinggalkan, jika yang meninggal itu mempunyai anak; jika orang yang meninggal tidak mempunyai anak dan ia diwarisi oleh ibu-bapanya (saja), maka ibunya mendapat sepertiga; jika yang meninggal itu mempunyai beberapa saudara, maka ibunya mendapat seperenam. (Pembagianpembagian tersebut di atas) sesudah dipenuhi wasiat yang ia buat atau (dan) sesudah dibayar hutangnya. (Tentang) orang tuamu dan anak-anakmu, kamu tidak mengetahui siapa di antara mereka yang lebih dekat (banyak) manfaatnya bagimu. Ini adalah ketetapan dari Allah. Sesungguhnya Allah Maha Mengetahui lagi Maha Bijaksana" ${ }^{15}$

Imam al-Qurtuby menjadikan ayat ini sebagai salah satu ayat al-Qur'an yang memberikan indikasi bahwa cucu mendapatkan harta warisan dari kakek, walaupun ayahnya telah meninggal dunia terlebih dahulu. Imam Qurtuby memaknai kata "awlad" yang terdapat dalam surah an-Nisa' ayat 11 bukan hanya untuk anak laki-laki (awladun adalah jamak dari kata waladun), akan tetapi juga

\footnotetext{
${ }^{15}$ Departemen Agama RI, Al-Qur'an Dan Terjemahan (Jakarta: Pustaka Amani, 2006).
} 
kepada makna keturunan ke bawah. ${ }^{16} 16$ Lebih jauh Imam al- Qurtuby memaknai kata "awlad" bukan hanya anak laki-laki, tetapi juga termasuk anak perempuan. Makna ini tersurat dari kandungan surah an-Nisaa' ayat 11 yang artinya ; "Allah mewajibkan kamu tentang "awlad" (anakanak kamu), buat seorang anak laki-laki (adalah) seperti bahagian dua anak perempua". Pandangan Imam Qurtuby ini bersumber/berasal dari tafsir Ibn Abbas terhadap makna awlad di dalam surah anNisaa' ayat $11 .{ }^{17}$

Sayyid Sabiq dan Yusuf Qaradhawy juga tidak menolak lembaga pergantian tempat ahli waris, karena mereka juga cenderung memberikan tafsir terhadap makna "awlad" dengan makna keturunan sampai ke bawah, yang mencakup tidak hanya keturunan dari garis laki- laki, tetapi juga keturunan dari garis anak perempuan..$^{18}$ Para ahli fiqh ini memandang persoalan pergantian tempat ahli waris sebagai suatu ijtihad, yang menempatkan cucu pada posisi ayahnya yang meninggal dunia terlebih dahulu dari kakeknya, dan ia berhak mendapatkan harta warisan dari kakeknya dan bagian harta warisan untuknya sesuai dengan hak pada posisi ayahnya. Pendapat kedua ulama ini, menemukan bahwa cucu walaupun orang tuanya terlebih dahulu meninggal dunia, namun peluang cucu untuk mendapatkan harta warisaan dari kakeknya tetap terbuka, apalagi cucunya tersebut berada dalam keadaan miskin, sehingga ia mesti mendapatkan bagian harta warisan dari kakeknya pada porsi dan psoisi ayahnya yang terlebih dahulu meninggal dunia. Ini adalah salah satu bentuk keadilan dalam hukum kewarisan Islam. ${ }^{19}$

Di Indonesia, pemikiran tentang adanya lembaga pergantian tempat ahli waris dalam hukum kewarisan Islam menurut Kompilasi Hukum Islam diyakini mengadopsi pemikiran salah satu pakar Hukum Islam Indonesia yang diperbincangkan oleh Hazairin. Hazairin menyatakan bahwa dalam hukum kewarisan Islam sebenarnya ada ruang bagi lembaga pergantian tempat ahli waris. Walaupun ijtihad yang dilakukannya memiliki cara pandang dan dasar hukum

\footnotetext{
${ }^{16}$ Imam Qurtuby, Tafsir Al-Qurtuby (Beirut: Dar al-Fikr, 2006).

17 Ibid.

18 Sayyid Sabiq, Fikih Sunnah, 12th ed. (Bandung: Darul Ma'arif, 1996); Yusuf AlQardhawi, Kumpulan Ijtihad Kontemporer (Jakarta: Firdaus, 1990).

${ }^{19}$ AlQardhawi, Kumpulan Ijtihad Kontemporer.
} 
yang berbeda tentang kedudukan ahli waris pengganti didalam nash, Hazairin merujuk sebagai landasan atau dasar hukum ahli waris pengganti dalam Q.S AnNisaa' [4]: 33:

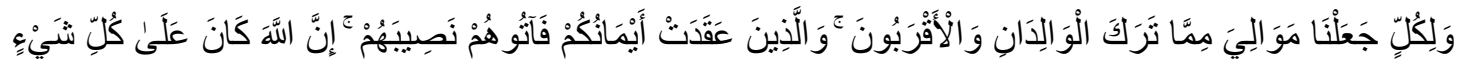

Terjemahannya:

“Bagi tiap-tiap harta peninggalan dari harta yang ditinggalkan ibu bapak dan karib kerabat, Kami jadikan pewaris-pewarisnya. Dan (jika ada) orang-orang yang kamu telah bersumpah setia dengan mereka, maka berilah kepada mereka bahagiannya. Sesungguhnya Allah menyaksikan segala sesuatu" ${ }^{20}$

"Nashibahum diterjemahkan sebagai bagian kewarisan, yaitu sesuatu bagian dari harta peninggalan, beralaskan pemakaian kata nashīb itu didalam ayat kewarisan lainnya, yaitu dalam Qur'an 4: 7, selain hubungannya sendiri dalam ayat 33 itu dengan "mimma taraka" dan sebagainya. Di dalam ayat 33 itu jelas bahwa nashīb itu disuruh berikan kepada mawāli itu dan bukan kepada orang yang tersimpul dalam likullin, sehingga mawāli itu adalah ahli-waris. Untuk menangkap maksud ayat 33 itu, coba lihat isi likullin itu dengan li Fulānin, dan ja'alnā diganti dengan ja'ala llāhu, sedangkan urusan perjanjian itu untuk gampangnya ditinggalkan saja, maka bunyi ayat menjadi “wa li Fulānin ja'ala'llāhu mawālia mimmā taraka 'l wālidāni wa 'l aqrabūna, fa ātūhum nashībahum".

Di sini si pewaris ialah ayah atau mak atau seorang-orang dari aqrabūn. Jika ayah atau mak yang mati maka istilah-istilah itu mempunyai timbalan berupa anak, anak yang mati ataupun anak yang menjadi ahli waris karena masih hidup. Jika tidak ada anakanak, baik anak-anak yang mati terlebih dahulu maupun anak-anak yang masih hidup pada saat matinya si pewaris, maka si pewaris itu bukan ayah atau mak tetapi seorang dari pada aqrabūn. Kepada anak-anak yang hidup telah pasti mesti diberikan nashībnya sebagai ahli-waris menurut IV: 11 a, b, c, tetapi disamping nashīb bagi anak-anak ini mesti pula diberikan nashīb kepada mawāli yang diadakan Allāh bagi si Fulān, dengan lain perkataan mawāli si Fulān ikut serta sebagai ahli-waris bagi ayah atau mak dan bukan si Fulān sendiri. Apa hubungan si

\footnotetext{
${ }^{20}$ Departemen Agama RI, Al-Qur'an Dan Terjemahan.
} 
Fulān dengan "mak atau ayah" yang mati itu, sehingga mawāli bagi si Fulān itu ikut pula menjadi ahli-waris bagi "mak atau ayah" itu sedangkan si Fulān sendiri tidak ikut menjadi ahli-waris? Berdasarkan prinsip umum bahwa Qur'ān meletakkan hubungan kewarisan atas dasar pertalian darah antara si-mati dengan anggota keluarganya yang masih hidup, maka si Fulān itu hanya dapat saya pikirkan sebagai anggota keluarga yang telah mati terlebih dahulu dari si pewaris, sedangkan mawāli si Fulān itu sebagai ahli waris bagi "ayah atau mak" itu hanya dapat saya pikirkan sebagai keturunan yang bukan anak bagi "ayah atau mak" itu. Hubungan antara si Fulān dan mawālinya, dalam hal mak atau ayah sebagai pewaris, hanya dapat dipikirkan ketiga juruan, yaitu mawālinya itu mungkin seorang dari wālidānnya, dalam hal mana si Fulān sendiri adalah pula keturunan bagi "mak atau ayah" itu; ataupun mungkin awlādnya, ataupun lebih jauh aqrabūnnya, dalam hal mana si Fulān sendiri adalah juga keturunan bagi "ayah atau mak" itu. Menurut jalan pikiran itu maka si Fulān itu, dalam hubungan "ayah atau mak" sebagai pewaris, termasuk keturunan bagi "ayah atau mak", sedangkan mawāli bagi si Fulān itu juga keturunan bagi "ayah dan mak" itu, tetapi bukan anak bagi ayah dan mak itu. Tetapi anak yang telah mati terlebih dahulu. Maka hubungan si Fulān dan mawālinya itu adalah hubungan si pewaris dengan keturunannya melalui mendiang anaknya si Fulān itu. ${ }^{21}$

Kebenaran konklusi tersebut hanya dapat diujikan kepada ayatayat Qur'ān yang membicarakan kewarisan bagi seseorang yang ada meninggalkan anak (walad) yaitu IV: 11 a, b, c, d, dengan dibandingkan pula dengan ayat-ayat Qur'ān yang membicarakan kewarisan bagi seseorang yang tidak ada baginya walad, yaitu IV: 11 e, f, IV: 12 f, g dan IV: 176. Jika tidak ada ketentuan Qur'ān mengenai mawāli dalam IV : 33 a itu, maka bilamana seseorang pewaris hanya meninggalkan keturunan yang bukan walad bagi dia, karena keturunan itu adalah cucu atau piut bagi si pewaris dari kelahiran via mendiang anak-anak si pewaris, maka akan berlakulah atas harta peninggalannya itu IV: 11 e, f, IV: 12 f, g dan IV : 176, sehingga cucu-cucu dan piut-piut itu akan tersingkir dari kewarisan dan hanya dipandang sebagai ūlū-

${ }^{21}$ Abubakar, Ahli Waris Sepertalian Darah: Kajian Perbandingan Terhadap Penalaran Hazairin Dan Penalaran Fiqih Madzhab. 
lqurbā saja (IV : 8) dalam berhadapan dengan orang tua dan saudara-saudara si pewaris yang akan berbagi harta peninggalan itu. Keadaan yang serupa ini akan bertentangan dengan seluruh fitrah yang ditanamkan Allāh dalam sanubri manusia, sehingga tidak ada sistem apapun yang akan dapat membenarkannya. Dari sudut cahaya ini, maka IV: 33 a itu termasuk rahmat yang sebesarbesarnya, yang telah diberikan Allāh kepada ummatNya. Jika tidak ada rahmat tersebut, maka apakah lagi dasar hukum yang dapat disalurkan dari Qur'ān untuk mendirikan hak kewarisan bagi lainlain aqrabūn yang tidak tersebut dalam ayat-ayat kewarisan dalam Qur'ān, seperti paman dan bibik, datuk dan nenek, cucu dan piut, d.s.b." 22

Hazairin menerangkan bahwa teks ayat 33 surah an-Nisaa', setelah mudaf ilaih lafaz kullun mengandung makna bahwa Allah mengadakan mawali untuk si fulan dari harta peninggalan orang tua dan keluarga dekat serta pihak allazina 'aqadat aymanukum, dan berikanlah kepada mawali itu (hak yang menjadi) bagiannya. Fulan dianggap sebagai ahli waris, karena diiringkan dengan kata walidain dan aqrabun yang menjadi pewaris. Apabila yang menjadi pewaris adalah orang tua (ayah-ibu), maka menurut hazairin ahli waris adalah anak atau mawali anak. Jika anak itu masih hidup, tentu merekalah yang secara serta merta mengambil warisan berdasarkan ayat 11 surah an-Nisa'. Mawali di sini hanya mungkin dipikirkan sebagai keturunan dari anak yang telah meninggal terlebih dahulu. Demikian dikatakan, karena dengan disebutnya nama ayah atau ibu maka otomatis ahli warisnya adalah anak. Tidak ada kemungkinan lain selain daripada mengartikan mawali dengan keturunan dari anak yang telah meningal dunia, karena hanya dengan keadaan inilah posisi ayah sebagai pewaris tidak akan bertukar. Hal ini lebih dikuatkan lagi karena Allah dalam surat ke4 (an- Nisa') ayat 33 menggunakan kata ja'ala yang semakna dengan khalaqa untuk menetapkan mawālî, yaitu menciptakan dari tidak ada menjadi ada. Dalam hukum kewarisan, proses penciptaan itu hanya dapat dibayangkan melalui kelahiran, sehingga ada hubungan antara pihak yang diangkat sebagai mawāli dan orang yang menjadi ahli waris

22 Ibid. 
tersebut. Penetapan ini tidak mungkin melalui cara lain, misalnya penunjukan. ${ }^{23} \mathrm{AlAl}$

Untuk menguatkan alur berpikir di atas, Hazairin mengujinya dengan ayat-ayat kewarisan yang lain, yaitu al-Qur'ān surat ke-4 (anNisa') ayat 11, 12, dan 176. Berdasarkan ketiga ayat ini, jika seseorang meninggalkan cucu dari anak yang telah meninggal terlebih dahulu bersama-sama dengan saudara dan orang tua, maka cucu tersebut akan tersingkir, dan yang berhak mewarisi hanyalah orang tua dan saudarasaudara dari yang meninggal terlebih dahulu itu. Oleh sebab itu, keadaan yang serupa ini akan bertentangan dengan seluruh fitrah yang ditanamkan Allah dalam sanubari manusia. ${ }^{24}$

Menurut Hazairin, kata al-wālidāni wa al-aqrbūna adalah sebagai fa'il dari kata taraka. Sedangkan kata mawāli adalah sebagai maf'ul bagi ja'alna. ${ }^{25}$ Artinya, bahwa setiap harta peninggalan yang ditinggalkan oleh ibu bapak dan kerabat terdekat, dijadikan Allah ahli wari-ahli warisnya. Hal ini berarti bahwa yang dijadikan Allah ahli waris-ahli waris tersebut adalah sebagai pengganti ahli waris yang telah meninggal dunia terlebih dahulu. ${ }^{26}$

Kata mawāli dimaksudkan oleh Hazairin dengan ahli waris pengganti dari mendiang anak, mendiang saudara, mendiang datuk atau nenek yang meninggal lebih dahulu sebelum pewaris. Menurut Hazairin, dalam berbagai kitab tafsir, kata mawāli diartikan semata-mata sebagai ahli waris langsung, sehingga semua kitab tafsir itu tidak ada gunanya. Hal ini disebabkan bahwa para penafsir mengartikan ayat mawāli itu "hanya jika ada mayat maka ada ahli waris langsungnya". Tidak terpikir oleh para mufassir itu bahwa ada kalanya ahli waris langsung itu sudah tidak ada. Akan tetapi Allah dalam al-Qur'ān surat ke- 4 (an-Nisa') ayat 33 mengadakan ahli waris lain, dalam hal ini ahli waris tidak langsung, yaitu ahli waris pengganti. ${ }^{27}$

${ }^{23}$ Ibid.

${ }^{24}$ Hazairin, Hukum Kewarisan Bilateral Menurut Qur'an Dan Hadits (Jakarta: Tinta Mas, 1981).

${ }^{25}$ Moh. Toha Yahya Umar and dkk., Perdebatan Dalam Seminar Hukum Nasional 1963 Tentang Faraid (Jakarta: Tinta Mas, 1964).

${ }^{26}$ Hazairin, Hukum Kewarisan Bilateral Menurut Qur'an Dan Hadits.

${ }^{27}$ Yahya Umar and dkk., Perdebatan Dalam Seminar Hukum Nasional 1963 Tentang Faraid. 
Menelusuri pemikiran Hazairin di atas, maka ahli waris pengganti itu disamakan kedudukannya dengan ahli waris yang digantikannya. Orang yang digantikan itu adalah sebagai pengganti antara ahli waris (pengganti) dengan pewaris (orang yang meninggal dunia terlebih dahulu dan meninggalkan harta warisan). Berdasarkan hal itu, maka ahli waris pengganti (mawaili) adalah keturunan (anak) pewaris, baik laki-laki maupun perempuan, saudara pewaris (laki-laki dan perempuan) maupun leluhur orang yang meninggal dunia sebagai pengganti dari ayah dan ibu. Bila dikaitkan dengan ahli waris pengganti dalam KHI, terdapat kesamaan dengan pemikiran Hazairin dalam menafsirkan ayat 33 surat an-Nisa'.

Dengan konstruksi berpikir sebagaimana yang dijelaskan di atas, maka golongan ahli waris menurut Hazairin adalah sebagai berikut: ${ }^{28}$

1. Keutamaan pertama: (a). Anak laki-laki dan perempuan, baik sebagai zawi alfurud maupun zawi al-qarabah beserta mawali, (b). Orang tua (ayah dan ibu) sebagai zawi al-furud dan (c). Janda atau duda sebagai zawi al-furud;

2. Keutamaan kedua: (a) Saudara laki-laki dan perempuan, baik sebagai zawi alfurud maupun zawi al-qarabah beserta mawali (b) Ibu sebagai zawi al-furud (c) Ayah sebagai zawi al-qarabah dan (d) Janda atau duda sebagai zawi al-furud;

3. Keutamaan ketiga: (a) Ibu sebagai zawi al-furud (b) Ayah sebagai zawi al qarabah dan (c) Janda atau duda sebagai zawi al-furud;

4. Keutamaan keempat: (a) Janda atau duda sebagai zawi al-furud (b) Mawali dari ibu dan (c) Mawali dari ayah.

\section{E. Ahli Waris Pengganti Menurut Hukum Islam}

Dalam kitab-kitab fiqh atau buku-buku yang ditulis para yuris Islam tidak mengenal sebutan ahli waris pengganti ataupun pergantian kedudukan ahli waris pengganti (plaatvervulling) seperti yang tersebut dalam Pasal 185 Kompilasi Hukum Islam. Ini merupakan dekonstruksi atas pendapat umum dalam hukum kewarisan Islam. Hukum Islam Normatif, sebagaimana kebanyakan menjadi pendapat umum dikalangan ahli hukum kewarisan menentukan bagian masing-masing ahli waris

${ }^{28}$ Abubakar, Ahli Waris Sepertalian Darah: Kajian Perbandingan Terhadap Penalaran Hazairin Dan Penalaran Fiqih Madzhab. 
berdasarkan apa yang tersebut dalam teks-teks suci Al Qur'an dan penguatan pengetahuan dari hadis Nabi Muhammad saw. Seperti sebagai berikut :

Allah mensyari'atkan bagimu tentang (pembagian pusaka untuk) anak-anakmu yaitu: bahagian seorang anak lelaki sama dengan bahagian dua orang anak perempuan: dan jika anak itu semuanya perempuan lebih dari dua, maka bagi mereka dua pertiga dari harta yang ditinggalkan; jika anak perempuan itu seorang sajamaka ia memperoleh separo harta. Dan untuk dua orang ibu-bapa, bagi masing-masingnya seperenam dari harta yang ditinggalkan, jika yang meninggal itu mempunyai anak; jika orang yang meninggal tidak mempunyai anak dan ia diwarisi oleh ibu-bapanya (saja), maka ibunya mendapat serpertiga; jika yang meninggal itu mempunyai beberapa saudara, maka ibunya mendapat seperenam. (Pembagian-pembagian tersebut diatas ) sesudah dipenuhi wasiat yang ia buat atau ( dan ) sesudah dibayar hutangnya. ( Tentang ) orang tuamu dan anak-anakmu, kamu tidak mengetahu siapa diantara yang lebih dekat (banyak) manfa'atnya bagimu. Ini adalah ketetapan dari Allah Sesungguhnya Allah Maha Mengetahui lagi Maha Bijaksana. Q.S An Nisa 11.

Dan bagimu (suami-suami ) seperdua dari harta yang ditinggalkan oleh isteriisterimu, jika mereka tidak mempunyai anak. Jika isterim-isterimu itu mempunyai anak, maka kamu mendapat seperempat dari harta yang ditinggalkan sesudah dipenuhi wasiat yang mereka buat atau (dan) sesudah dibayar hutangnya. Para isteri memperoleh seperempat harta yang kamu tinggalkan jika kamu tidak mempunyai anak. Jika kamu mempunyai anak, maka para isteri memperoleh seperdelapan dari harta yang kamu tinggalkan sesudah dipenuhi wasiat yang kamu buat atau (dan) sesudah dibayar hutang-hutangmu. Jika seseorang mati, baik laki-laki maupun perempuan seorang saudara laki-laki (seibu saja) atau seorang saudara perempuan (seibu saja), maka bagi masingmasing dari kedua jenis saudara itu seperenam harta. Tetapi jika saudar- saudara seibu itu lebih dari seorang, maka mereka bersekutu dalam yang sepertika itu, sesudah dipenuhi wasia yang dibuat olehnya atau sesudah dibayar hutangnya dengan tidak memebrik mudharat (kepada ahli waris ). (Allah m netapkan yang 
demikian itu sebagai ) syari'at yang benar-benar dari Allah, dan Allah Maha Mengetahui lagi Maha Penyantun. Q.S An Nisa 12.

Menurut kebanyakan para yuris Islam, teks suci pada ayat di atas telah rinci menjelaskan tentang pembagian warisan bagi orang muslim. Mustahil ada celah untuk mempengaruhi, baik secara sosiologis maupun filosofis. Ini berarti masalah kewarisan Islam adalah final dan qoth'i ${ }^{29}$

Memahami salah satu dari sekian ayat tentang hukum waris Islam dalam teks suci Al Qur'an di atas, hukum kewarisan Islam secara mendasar dipahami sebagai ekspresi langsung dari teks-teks suci sebagaimana pula yang telah disepakati keberadaannya. Seperti yang dirincikan A Sukris Sarmadi dalam bukunya Dekontruksi Hukum Progresif Ahli Waris Pengganti Kompilasi Hukum Islam, sebagai berikut: ${ }^{30}$

1. Cara pembagian antara laki-laki dengan perempuan adalah berbanding $2: 1$ berdasarkan Q.S An Nisa ayat 11;

2. Anak perempuan yang berjumlah lebih dari dua orang, secara kolektif memperoleh bagian dua pertiga dan jika ia hanya seroang saja akan mendapatkan bagian seperdua, berdasarkan Q.S. An Nisa ayat 11;

3. Ayah dan ibu mendapat seperenam bagian jika pewaris anak. Jika pewaris tidak memiliki anak, maka bagian ibu menjadi sepertiga kecuali jika pewaris walaupun tidak punya anak tetapi punya saudara-saudara maka ia hanya memperoleh seperenam, berdasarkan Q.S An Nisa ayat 11;

4. Harta waris adalah bagian harta sisa setelah harta peninggalan pewaris dibayarkan untuk wasiat dan segala utangnya jika ada, berdasarkan Q.S. An Nisa ayat 11;

${ }^{29}$ Qoth'I maksudnya petunjuk yang telah jelas sebagai lawan dari zhonni yang artinya ada kesamaran. Dalam kajian ushul figh untuk maksud tersebut di atas diistilahkan dengan Qoth'I al Dilalah ( petunjuk yang jelas maksdnya ) dan Zhonni al Dilalah ( petunjuk yang tidak jelas maksudnya.).A. Sukris Sumardi, Membangun Refleksi Nalar, Filsafat Hukum Islam Paradigmatik (Yogyakarta: Pustaka Prisma, 2007).

${ }_{30}$ A. Sukris Sumardi, Dekontruksi Hukum Progresif Ahli Waris Pengganti Kompilasi Hukum Islam (Yogyakarta: Aswaja Pressindo, 2012). 
5. Suami memperoleh seperdua dari istrinya yang meninggal dunia (pewaris) jika mereka tidak mempunyai anak dan jika mereka anak maka bagiannya menjadi seperempat, berdasarkan Q.S. An Nisa ayat 12;

6. Istri akan memperoleh seperempat dari suaminya yang meninggal ( pewaris ) jika suami tidak mempunyai anak, tetapi ia akan memperoleh seperdelapan jika ia mempunyai anak, berdasarkan Q.S An Nisa ayat 12;

7. Ahli waris, apabila hanya ada seorang saudara laki-laki atau saudara perempuan saja dari mayit ( pewaris ) tanpa adanya ayah dan anak dari pewaris maka masing- masing mereka memperoleh seperenam dan jika mereka lebih dari satu orang secara kolektif mereka memperoleh sepertiga, berdasarkan Q.S An Nisa ayat 12;

8. Pewaris yang meninggal dunia tanpa meninggalkan anak, tetapi mempunyai saudara perempuan, maka bagi saudara perempuan tersebut memperoleh dua pertiga. Apabila mereka dua orang atau lebih maka akan memperoleh dua pertiga (2/3) berbagai sesema mereka. Teknis ini terjadi pula jika pewaris meninggalkan saudara laki-laki maka ia akan memperoleh bagian pusaka saudaranya. Jika mereka berbilang, lelaki dan perempuan, mereka memperolehnya secara kolektif dengan perbandingan untuk seorang lelaki seumpama seorang perempuan berdasarkan Q. S. An Nisa ayat 178.

Berdasarkan pendapat umum dalam hukum Islam yang dipahami dari ayat-ayat di atas, tidak ada istilah waris pengganti ataupun pergantian kedudukan warisan (plasatsvervulling). Seseorang memperoleh hak waris dikarenakan ditentukan dalam hukum itu sendiri berhak menerima waris dengan bagian yang berbeda-beda. Misalnya tentang anak- anak memperoleh hak bagi anak lelaki beroleh dua kali lipat dari anak perempuan. Jika anak lelaki sendirian atau bersama dengan anak lelaki lain maka mereka mendapat ushubah yakni menghabiskan semua sisa harta. Sedangkan anak perempuan memperoleh $1 / 2$ bila sendirian tanpa anak lelaki atau 2/3 jika berjumlah lebih dari seorang tanpa ada anak lelaki. Lalu bagaimanakah jika tidak ada anak-anak sedangkan yang ada adalah para cucu dari pewaris? Pendapat 
umum dalam hukum Islam selama ini mengqiyaskan pola pembagian sebagaimana terhadap anak-anak dengan ketentuan dua keadaan yang berbeda, sebagai berikut: ${ }^{31}$

1. Pancar lelaki, maksudnya anak turun dari anak lelaki, baik ia lelaki ataupun perempuan;

2. Pancar perempuan, maksudnya anak turun dari anak perempuan baik ia lelaki maupun perempuan.

Tentang anak-anak pancar lelaki (para cucu pancar lelaki) memperoleh ushubah (mengambil semua sisa) jika si pewaris tidak mempunyai anak dan tidak ada ahli waris yang lain. Jika ia bersama dengan cucu lelaki pancar lelaki lain maka ia berbagi sama dan jika bersama dengan cucu perempuan pancar lelaki, maka cucu lelaki pancar lelaki memperoleh dua bagian $(2: 1){ }^{32}$ Sedangkan cucu perempuan pancar lelaki memperoleh bagian separoh (1/2) bila ia hanya sendirian dan $2 / 3$ bila ia dua orang atau lebih. Dan jika ia bersama dengan cucu lelaki pancar lelaki maka ia memperoleh bagian separoh dari saudaranya lelaki (cucu pancar lelaki). ${ }^{33}$ Ini merupakan dialektis atas pemahaman terhadap anak lelaki dan anak perempuan pewaris dengan metode berfikir qias (analogi). Mereka juga memperkuat pendapat tersebut dengan dasar pendapat Ibnu Mas'ud (sahabat rasulullah saw) yang mengatakan bahwa nabi swa memahamkan demikian, sebagai berikut: ${ }^{34}$

Huzil Ibmu Surujil berkata, ditanyai Abu Musa tentang anak perempuan dan cucu perempuan pancar lelaki, maka Abu Musa berkata bahwa anak perempuan memperoleh separoh $(1 / 2)$ dan saudara perempuan separohnya (1/2). Lalu aku datang kepada Ibnu Mas'ud ram aka ditanyakan kepadanya, lalu Ibmu Mas'ud ra mengabarkan perkataan Abu Musa ra berkata, sungguh aku sesat jika tidak termasuk orang yang diberi petunjuk, aku memutus dengan apa yang diputus oleh nabi saw yaitu anak perempuan separoh ( $1 / 2)$, cucu perempuan pancar lelaki seperenam (1/6) sebagai penyempurna dua pertiga dan sisanya untuk anak perempuan. Maka aku datang kepada Abu Musa ra dan aku kabarkan

${ }^{31}$ Ibid.

${ }^{32}$ Faturrahman, Ilmu Waris (Bandung: Al Ma'arif, 1981).

33 Ibid.

${ }^{34}$ Muhammad bin Ismail Al Bukhori, Hadits Shahih Bukhori, 1st ed. (Cairo: Daarul ibn Hisyam, 2003). 
perkataan Ibnu Mas'ud maka Abu Musa berkata, aku tidak pernah ditanyai tentang itu selama ini, (HR. Bukhari)

Menggenai cucu lelaki atau perempuan pancar perempuan, mereka dianggap tidak berhak atas waris bila masih ada far'u waris berupa ashabul furud (orang-orang yang telah ditentukan bagiannya) dan ashabah (orang yang menghabisi sisa harta). Mereka digolongkan termasuk sebagai dzawil arham yakni golongan yang bukan ashabul furud dan ashabah. ${ }^{35}$ Alasan umum pendapat mereka adalah bahwa para cucu perempuan pancar perempuan tidak dibicarakan dalam teks-teks al Qur'an kelompok ini disponsori oleh mayoritas jumhur ulama dalam madzahab Sunni (terutama imam empat madzhab). Dengan kata lain, tidak ditemukan ada istilah waris pengganti sebab orang-orang tertentu berhak atas suatu fard (perolehan bagian waris) yang disebut dengan ashabul furud dan ashabah. Sedangkan dzawil arham adalah orang yang memperoleh hak dikarenakan tidak ada ashabul furud dan ashabah. $^{36}$

\section{F. Ahli Waris Pengganti Menurut KHI}

Sebelumnya, hakim yang ditugaskan di pengadilan Agama berasal dari ulama local, yang mana mereka bebas untuk menggunakan dan memilih berbagai macam fiqh yang beragam sebagai sumber materil dalam peradilan. Baru pada tahun 1958, kementrian Agama mengeluarkan surat No. B/1/735/1958 yang merekomendasikan penggunaan 13 kitab fiqh bagi hakim pengadilan Agama sebagai refrensi, yaitu (1) Hasyiyah Kifayah al-Akhyar oleh Ibrahim bin Muhammad al-bajuri (w.1860 M); (2) Fath al-Mu'in oleh Zain ad-Din al- malibari (w. sekitar 975 H); (3) Hasyiyah 'ala at-Tahrir oleh 'Ali bin Hijazi bin Ibrahim al- Syarqawi (w. 1737); (4) Syarh Kanz ar-Ragibin oleh al-Qalyubi (w. 1659 M); (5) Fath al- Wahhab oleh Abu Yahya Zakariyya al-ansari (w. 1520 M); (6) Tuhfah al-Muhtaj oleh Syihab ad-Din Ahmad bin Hajar al-Haytami; (7) Targib al-Musytaq oleh Syihab ad-Din Ahmad bin Hajar al-Haytami; (8) al-Qawani asy-Syar'iyya li Ahl al-Majalis al-Hukumiyyat wa al-

\footnotetext{
${ }^{35}$ Faturrahman, Ilmu Waris.

${ }^{36}$ Sumardi, Dekontruksi Hukum Progresif Ahli Waris Pengganti Kompilasi Hukum Islam.
} 
Ifta'iyyat oleh Sayyid 'Usman bin Yahya (1822-1914 M); (9) al-Qawani asy-Syar'iyya oleh Sayyid 'Abd Allah bin Sadaqah San'an Dahlan; (10) al-Fara'id oleh Syamsuri; (11) Bugyah al-Mustarsyidin oleh Husay al-Ba'alawi; (12) al-Fiqh 'ala al-Mazahib alArba'ah oleh 'Abd ar-Rahman al-Jaziri (1882-1941 M); dan (13) Mugni al- Muhtaj oleh Muhammad asy-Syarbini (w. 1569). ${ }^{37}$

Semua kitab fiqh tersebut berasal dari mazhab Syafi'i, kecuali kecuali kitab alFiqh 'ala al-Mazahib al-Arba'ah. Permilihan kitab-kitab tersebut didasari alasan Kementrian Agama saat itu didominasi oleh kalangan NU dan konon kitab-kitab inilah yang sering dibaca ulama. Pemilihan kitab-kitab ini juga untuk mencegah perbedaan putusan dikalangan hakim Pengadilan Agama, walaupun pada faktanya, kasus-kasus kontemporer seperti diskursus poligami dan perceraian tidak bisa diakomudir lewat kitab-kitab ini.

Pada saat bersamaan, muncul gagasan untuk membentuk mazhab Indonesia yang dikemukakan oleh Hasbi ash-Shidiqie dan Hazairin. Di tahun 1980-an, ide ini kembali dihidupkan oleh Munawir Syadzali (1925-2005) yang menjabat sebagai Mentri Agama dalam dua periode (1983-1993). Syadzali mengusulkan sebuah ide yang disebut 'reaktualisasi hukum islam' dengan pembagian kewarisan sama rata bagi laki-laki dan perempuan. Semua gagasan ini menunjukkan upaya pentingnya memasukkan hukum Islam kedalam hukum positif Negara. Dalam konteks ini, ide untuk membuat Kompilasi muncul ke permukaan.

Bustanul Arifin yang saat itu menjabat sebagai ketua Divisi Pengawasan Peradilan Agama dan Mahkamah Agung memainkan peran penting dibelakang pembentukan Kompilasi. Ketika Divisi khusus ini terbentuk, relasi antara Kementrian Agama dan Mahkama Agung semakin menguat, hingga mencapai titik kulminasi dengan disahkannya UU No. 7 Tahun 1989 tentang Pengadilan Agama. UU ini memberikan jurisdiksi penuhterhadap PA untuk menanggani kasus-kasus dalam hukum Keluarga Islam, yaitu perkawinan, perceraian, rujuk, kewarisan, wasiat, hibah, dan wakaf. Pada akhirnya mengharuskan pemerintah untuk

\footnotetext{
${ }^{37}$ Euis Nurleaelawati, Modernization, Tradition and Identity: The Kompilasi Hukum Islam and Legal Practice in the Indonesian Religious Courts (Amsterdam: Amsterdam University Press, 2010).
} 
mengesahkan hukum materil bagi pelaksanaan proses peradilan. Di tahun 1985, Bustanul Arifin, bersama dengan hakim-hakim PA dan pejabat dilingkungan Peradilan Agama, mengusulkan sebuah proposal kepada presiden; mengenai perlunya mengadakan kodifikasi aturan hukum keluarga Islam. Periode ini adalah masa-masa dimana presiden sedang menggalakkan perlunya asas tunggal dalam kepemimpinannya. Bustanul meyakikan presiden bahwa muslim Indonesia meyakini perspektif yang berbeda-beda tentang fiqh dan hal ini akan menjadi ancaman serius untuk pancasila.pembentukan Kompilasi akan menghalangi ancaman ini, kerena Kompilasi akan menyatukan beragam perbedaan tersebut. Karena timing dan alasan pengajuan proposal tersebut sesuai dengan kepentingan politik, Presiden menyetujui untuk membentuk komisi kerja sama antara Kementrian Agama dan Mahkama Agung, dengan dikeluarkannya Surat Keputusan Bersama (SKB) No. 07/KMA/1985, yang kemudian diikuti dengan SKB No. 25/KMA/1985. ${ }^{38}$

Langkah kedua adalah melakukan wawancara kepada 181 ulama dari 10 area terpilih, yakni Aceh, Medan, Palembang, Padang, Jawa Tenggah, Jawa Timur, Jawa Barat, Unjung Pandang, Mataram dan Banjarmasin. Hal ini juga bertujuan agar ulama merasa suara mereka didengar dan dipertimbangkan. Mereka akan merasa bangga di hadapan santri, jika kitab fiqh yang dipelajari di pesantren mereka, menjadi salah satu sumber rujukan dalam forum resmi ke-Negara-an. ${ }^{39}$

Langkah ketiga adalah menyaring yurispudensi dari Pengadilan Agama. Berkas putusan dari PA dikumpul dalam $16 \mathrm{buku}$, yang kemudian dianalisis untuk menemukan argumentasi atau alasan terkuat dibalik isu tertentu. Langkah keempat adalah melakukan analisis perbandingan terhadap hukum keluarga yang di terapkan di berbagai Negara-Negara muslim. Seperti Mesir, Maroko, dan Turki adalah Negara-Negara yang dipilih untuk melaksanakan studi perbandingan. Kemudian yang terakhir, setelah data terkumpul, komisi memulai untuk membuat rencana, yang kemudian dipresentasikan dalam seminar nasional tertangal 2-6

\footnotetext{
38 Ibid.
}

${ }^{39}$ Ibid. 
Februari 1988 dan diikuti 124 partisipan. Walaupun rancangan Kompilasi sudah disetujui pada seminar, pengesahannya di tunda sampai PA memiliki UU khusus yang diwujudkan ditahun 1989. Di tahun 1991, Kompilasi ditanda tangani Soeharto dan diresmikan dengan instruksi Presiden (Inpres) No. 1/1991, diikuti dengan keputusan Mentri Agama (KMA) No. 154/1991, sebagai intruksi untuk menjadikan Kompilasi sebagai sumber materil di lingkungan Peradilan Agama. ${ }^{40}$

Konsep ahlih waris pengganti di dalam Kompilasi Hukum Islam ini sebagaimana dalam BW dikenal dengan istilah Plaatsvervulling. Pemberian kepada ahlih waris penganti (terutama bagi para cucu), walaupun tidak seperti dalam BW, ini sejalan dengan doktrin mawali Hazairin dan cara succession dan prinsip representasi yang dapat dipakai oleh golongan syi'ah. Namun demikian, dalam Kompilasi Hukum Islam tersebut bagian ahli waris pengganti dibatasi, tidak boleh melebihi bagian ahli waris yang sederajat dengan ahli waris yang diganti. ${ }^{41}$

Ketentuan ahli waris pengganti atau pergantiang kedudukan ahli waris orang tuanya telah meninggal terlebih dahulu dari pewaris, pada hakekatnya diatur dalam KHI. Hal ini termaktub dalam pasal di bawah ini:

Pasal 185

1. Ahli waris yang meninggal lebih dahulu dari pada sipewaris maka kedudukannya dapat digantikan oleh anaknya, kecuali mereka yang tersebut dalam Pasal 173.42

2. Bagian ahli waris pengganti tidak boleh melebihi dari bagian ahli waris yang sederajat dengan yang diganti.

Dari rumusan Pasal $185 \mathrm{KHI}$ mengenai ahli waris pengganti dapat dipahami bahwa: ${ }^{43}$

\footnotetext{
${ }^{40}$ Ibid.

${ }^{41}$ Suparman Usman and Yusuf, Figh Mawaris (Jakarta: Gaya Medium Pratama, 2008).

${ }^{42}$ Pengecualian tersebut dalam Pasal 173 adalah karena adanya halangan khusus berbunyi, “ Seorang terhalang menjadi ahli waris apabila putusan hakim yang telah mempunyai kekuatan hukum yang tetap, dihukum karena : a.Dipersalahkan telah membunuh atau mencoba membunuh atau menganiaya berat para pewaris; b. Dipersalahkan secara memfitnah telah mengajukan pengaduan bahwa pewaris telah melakukan suatu kejahatan yang diancam dengan hukuman 5 tahun penjara atau hukuman yang lebih berat. Sumardi, Dekontruksi Hukum Progresif Ahli Waris Pengganti Kompilasi Hukum Islam.
} 
Ayat pertama, secara tersurat mengakui ahli waris pengganti, yang merupakan hal baru untuk hukum kewarisan islam. Karena di Timur Tengah-pun belum ada Negara yang melakukan seperti ini, sehingga mereka perlu menampungnya dalam lembaga wasiat wajibah, ayat pertama ini juga menggunakan kata "dapat" yang tidak mengandung maksud imperatif. Hal ini berarti bahwa dalam keadaan tertentu dimana kemashlahatan menghendaki keberadaan ahli waris pengganti maka keberadaannya dapat diakui, namun dalam keadaan tertentu bila keadaan tidak menhendaki, maka ahli waris tersebut tidak berlaku.

Ayat pertama ini secara tersirat mengakui kewarisan cucu melalui anak perempuan yang terbaca dalam rumusan "ahli waris yang meningal lebih dahulu" yang diganti anaknya itu mungkin laki-laki dan mungkin pula perempuan. Ketentuan ini menghilangkan sifat diskriminatif yang ada pada hukum kewarisan ahlu sunnah. Ketentuan ini sesuai dengan budaya Indonesia yang kebanyakan menganut kekeluargaan parental dan lebih cocok lagi dengan adat minangkabau yang justru menggunakan nama "cucu" untuk anak dari anak perempuan tersebut.

Pada ayat kedua, yang menegaskan perolehan ahli waris pengganti tidak boleh melebihi ahli waris lain yang sederajat. Untuk lebih jelasnya, berikut ilustrasi yang menggambarkan implementasi aturan tersebut: "P meninggalkan ahli waris yang terdiri dari istri (A), anak perempuan (B), dan cucu perempuan dari anak laki-laki (C). Berdasarkan fiqh kewarisan Sunni, A mendapatkan 1/8, B mendapatkan 1/2, dan C mendapatkan 1/6 (takmulah as-sulusain). Ada sisa radd 5/24 yang akan diberikan kepada B dan C. Sementara menurut Pasal 185 ayat (1) KHI, A mendapatkan 1/8 dan sisa 7/8 diberikan kepada B dan C sebagai ‘as\}abah . C sebagai ahli waris pengganti mendapatkan 14/24 karena menggantikan kedudukan ayahnya, sementara B mendapatkan 7/24. Menyadari hal tersebut, dimana C sebagai ahli waris pengganti mendapatkan bagian yang lebih besar daripada bibinya, maka ditetapkan pasal 185 ayat (2). Dengan

\footnotetext{
${ }^{43}$ Amir Syarifuddin, Pembaruan Pemikiran Dalam Hukum Islam (Padang: Angkasa Raya, 1993).
} 
demikian, B dan C berbagi sisa warisan sama rata; masing-masing mendapatkan 7/16."

Aturan pembatasan penerimaan bagian bagi ahli waris pengganti ini menimbulkan dua perbedaan pendapat di kalangan praktisi dan akademisi hukum Islam. Sebagaimana yang dicatat Euis Nurlaelawati, Amir Syarifuddin, salah seorang perumus KHI, mengatakan bahwa aturan tersebut dibuat untuk menetralisir ketidakadilan, seperti contoh di atas. Roihan Rasyid, mantan ketua PTA Palembang, malah mengusulkan bahwa seharusnya harus ada persetujuan dari zawu al-furud lain seperti ayah, ibu, suami, istri, saudara laki-laki atau saudara perempuan, karena konsep ahli waris pengganti tentu akan mengurangi bagian mereka. ${ }^{44}$

Sementara dengan adanya pasal 185 Kompilasi Hukum Islam maka cucu lakilaki ataupun perempuan pancar perempuan boleh berhak waris sebagaimana hak para cucu laki- laki atau perempuan pancar laki-laki. Dalam pasal 185 Kompilasi Hukum Islam dapat ditafsirkan sebagai berikut:

1. Cucu laki-laki atau perempuan pancar laki-laki atau anak turun-anak lakilaki pewaris mengambil saham ashabah sebagian orang tua mereka. Baik ketika ia sendirian tunggal laki-laki ataupun tunggal perempuan. Apabila ia berkumpul laki-laki dan perempuan, mereka mengambil bagian ashabah orang tua mereka kemudian diantara mereka berbagi 2:1, lakilaki memperoleh bagian yang sama dengan dua perempuan berdasarkan pada Q.S.An Nisa ayat 11,12 dan 76.

2. Cucu laki-laki atau perempuan pancar perempuan atau anak turun anak perempuan pewaris mengambil saham anak perempuan $1 / 2$ fard. Baik ketika ia sendirian tungal laki-laki ataupun tunggal perempuan, berbilang tunggal laki-laki ataupun perempuan berbagi sama rata 1:1, dan jika berkumpul laki-laki dan perempuan berbagi 2:1, lelaki memperoleh bagian yang sama dengan bagian dua orang perempuan (Pasal 185) Q.S.

\footnotetext{
${ }^{44}$ Euis Nurlaelawati, "The Debate on Muslim Family Law Reforms in Indonesia: The Case of Representation of Heirs and Obligatory Bequest,'" Al-Jami'ah 41, no. 2 (2003): 250.
} 
An Nisa ayat 11,12 dan 76. Para cucu laki-laki dan perempuan, pancar laki-laki atau perempuan tidak boleh memperoleh saham melebihi dari perolehan orang-orang yang sederajat dengan orang yang mereka ganti (Pasal 185). Jika mereka menggantikan anak laki-laki padahal ada anak perempuan pewaris, maka bagian mereka tidaklah boleh melebihi bagian dari anak perempuan dimaksud. Alasannya karena derajat anak perempuan adalah seperti derajat orang yang diganti (anak lelaki) sedang orang yang menggantikan naik derajatnya karena matinya orang tua mereka. ${ }^{45}$

Sebelum menutup penjelasan mengenai aturan ahli waris pengganti di Indonesia, patut diketahui bahwa Indonesia juga menerapkan sistem wasiat wajibah dalam KHI. Berbeda dengan negara-negara Timur Tengah yang menafsirkan 'al-aqrabun' dalam QS. al-Baqarah [2]: 180 sebagai cucu yatim, Indonesia mendefinisikannya sebagai anak atau orangtua angkat. Wilayah cakupan ini kemudian diperluas ke ranah keluarga yang berbeda agama dengan yurisprudensi Mahkamah Agung. Mengapa Indonesia lebih memilih lembaga 'ahli waris pengganti' dibanding wasiat wajibah untuk mengakomodir kewarisan cucu yatim? Menurut Euis Nurlaelawati, pakar hukum perdata Islam di Indonesia, masalah anak dan orangtua angkat tidak bisa diselesaikan dengan sistem ahli waris pengganti karena harus ada hubungan nasab dalam sistem kewarisan, maka KHI memilih sistem tersebut untuk cucu yatim. ${ }^{46}$

\section{G. Penutup}

Pada dasarnya berbagai kitab fiqh klasik tidak ada konsep perggantian ahli waris sebagaiman dalam konsep Kompilasi Hukum Islam yang diadopsi dari teori hazairin, namun fiqh telah mengenal ahli waris yang meningal lebih dahulu dari pewaris yang digantikan kedudukannya oleh anak dan keturunannya. Namun istilah yang digunakan bukan ahli waris pengganti, akan tetapi pada hakikatnya

${ }^{45}$ Sumardi, Dekontruksi Hukum Progresif Ahli Waris Pengganti Kompilasi Hukum Islam.

46 Nurlaelawati, "'The Debate on Muslim Family Law Reforms in Indonesia: The Case of Representation of Heirs and Obligatory Bequest.'" 
tetap menggandung makna ahli waris pengganti, namun yang dianggap mempunyai kedudukan sebagai ahli waris pengganti hanyalah keturunan dari anak laki-laki baik laki-laki atau perempuan yang meningal lebih dahulu dari pewaris. Maksudnya hanya cucu laki-laki atau perempuan dari anak laki-laki yang dapat menerima warisan dari kakeknya.

Adanya istilah ahli waris pengganti dalam ranah Kompilasi Hukum Islam di Indonesia berdasarkan produk ijtihad agar cucu anak perempuan baik laki-laki ataupun perempuan mendapatkan haknya yang selama ini tidak dimasukkan dalam hak ahli waris. Pada intinya bahwa telah terjadi dekonstruksi hukum kewarisan Islam di Indonesia yang selama ini dianggap qathi'iy.

\section{Daftar Pustaka}

Abubakar, Al Yasa. Ahli Waris Sepertalian Darah: Kajian Perbandingan Terhadap

Penalaran Hazairin Dan Penalaran Fiqih Madzhab. Jakarta: INIS, 1998.

al-Asqalani, Ahmad bin Ali bin Hajar. Fath Al-Bari Syarh Sahih Al-Bukhari. Beirut: Dar ar-Riyan li at- Turas, 1986.

AlQardhawi, Yusuf. Kumpulan Ijtihad Kontemporer. Jakarta: Firdaus, 1990.

As Shabuni, Muhammad Ali. Terjemahan: Hukum Waris Dalam Syari'at Islam.

Bandung: Diponegoro, 1988.

Azhari, Ahmad. Hukum Kewarisan Islam. Pontianak: FHLM Untan Press, 2008.

Al Bukhori, Muhammad bin Ismail. Hadits Shahih Bukhori. 1st ed. Cairo: Daarul ibn Hisyam, 2003.

Coulson, N.J. Succession in the Muslim Family. Cambridge: The University Press, 1971.

Departemen Agama RI. Al-Qur'an Dan Terjemahan. Jakarta: Pustaka Amani, 2006.

Djatnika, Rahmat. Sosialisasi Hukum Islam Dalam Kontroversi Pemikiran Islam Di

Indonesia. 2nd ed. Bandung: Remaja Rodakarya, 1993.

Faturrahman. Ilmu Waris. Bandung: Al Ma'arif, 1981.

Hazairin. Hukum Kewarisan Bilateral Menurut Qur'an Dan Hadits. Jakarta: Tinta Mas, 1981.

Hoballah, Hisyam. Understanding Islamic Law: From Classical and Contemporary.

Oxford: Altamira Press, 2006. 
Nurlaelawati, Euis. “'The Debate on Muslim Family Law Reforms in Indonesia: The Case of Representation of Heirs and Obligatory Bequest.'" Al-Jami'ah 41, no. 2 (2003): 250.

Nurleaelawati, Euis. Modernization, Tradition and Identity: The Kompilasi Hukum Islam and Legal Practice in the Indonesian Religious Courts. Amsterdam: Amsterdam University Press, 2010.

Qurtuby, Imam. Tafsir Al-Qurtuby. Beirut: Dar al-Fikr, 2006.

Rofiq, Ahmad. Fiqih Mawaris. II. Jakarta: PT. Raja Grafindo Persada, 1995.

Sabiq, Sayyid. Fikih Sunnah. 12th ed. Bandung: Darul Ma'arif, 1996.

Bin Salim, Muhammad. Fiqih Mawaris. 1st ed. Tarim (Hadramaut): Dar al-Fikr, 2005.

Sumardi, A. Sukris. Dekontruksi Hukum Progresif Ahli Waris Pengganti Kompilasi Hukum Islam. Yogyakarta: Aswaja Pressindo, 2012.

- - - Membangun Refleksi Nalar, Filsafat Hukum Islam Paradigmatik. Yogyakarta: Pustaka Prisma, 2007.

Syarifuddin, Amir. Pembaruan Pemikiran Dalam Hukum Islam. Padang: Angkasa Raya, 1993.

Thalib, Sajuti. Hukum Kewarisan Islam Di Indonesia. 8th ed. Jakarta: Sinar Grafika, 2004.

- - - . Hukum Kewarisan Islam Di Indonesia. Revii Cet. Jakarta: Sinar Grafika, 2016.

Usman, Suparman, and Yusuf. Fiqh Mawaris. Jakarta: Gaya Medium Pratama, 2008.

Yahya Umar, Moh. Toha, and dkk. Perdebatan Dalam Seminar Hukum Nasional 1963 Tentang Faraid. Jakarta: Tinta Mas, 1964. 